\title{
PENGGUNAAN ANALOGI DALAM PEMBELAJARAN KIMIA
}

\author{
I Wayan Suja \\ Jurusan Pendidikan Kimia, Fakultas Matematika dan IImu Pengetahuan Alam \\ Universitas Pendidikan Ganesha \\ Singaraja, Indonesia \\ e-mail: suja_undiksha@yahoo.co.id
}

\begin{abstract}
Abstrak
Penelitian ini bertujuan untuk menentukan dan mendeskripsikan analogi-analogi yang biasa digunakan oleh guru-guru dalam mengajarkan konsep-konsep Kimia di SMA. Penelitian dilakukan pada tahun 2013 dengan melibatkan masing-masing dua orang guru Kimia dari seluruh SMA Negeri dan Swasta yang memiliki Jurusan IPA di Kota Singaraja. Hasil penelitian menunjukkan, guru-guru menggunakan tidak kurang dari 12 kelompok analogi dalam pembelajaran Kimia. Penggunaan analogi-analogi tersebut masih bersifat tunggal dan belum disertai pemetaan kemiripan fitur-fitur analog dengan konsep target. Kondisi itu berpeluang menimbulkan terjadinya over interpretasi dan miskonsepsi bagi siswa.
\end{abstract}

Kata kunci: analogi, kimia, target

\begin{abstract}
This study aimed to determine and describe the analogies used by teachers in teaching of Chemistry concepts in the High School. The study was conducted in 2013 involving each two Chemistry teachers from all public and private high school that has a Science Department in the city of Singaraja. The results showed that teachers use no less than 12 groups of analogy in learning Chemistry. The use of analogies are still single and have not been accompanied similarity mapping features analogous to the target concept. The condition is likely to lead to the occurrence of over-interpretation and misconceptions for students.
\end{abstract}

Keywords: analogy, chemistry, target

\section{PENDAHULUAN}

Salah satu karakteristik
pembelajaran Kimia adalah adanya
kajian pada level submikroskopis, yang
meliputi struktur, dinamika, dan
transformasi partikel-partikel materi,
seperti atom, ion, dan molekul. Kajian
submikroskopis menyebabkan ilmu
kimia bersifat abstrak dan perlu
penalaran tingkat tinggi untuk

memahaminya. Selain itu, konsepkonsep kimia juga cenderung saling berkaitan satu dengan lainnya, sehingga sulit dipahami oleh sebagian pebelajar (Suja, 2011). Untuk membantu pebelajar dalam memvisualiasasikan konsep-konsep abstrak dan membangun konsep-konsep kimia, para pendidik biasanya menggunakan model atau analogi. Bahkan, berbagai konsep 
abstrak dalam pembelajaran kimia tidak dapat dijelaskan secara efektif tanpa menggunakan model atau analogi (Harrison, \& Coll, 2008).

Menurut Zook (dalam Slavin, 2008), penggunaan analogi dapat membantu pebelajar untuk memahami informasi baru dengan menghubungkannya pada konsepkonsep yang telah ada dalam ruang memori pebelajar. Pemilihan analogi perlu mempertimbangkan dua hal berikut: 1) analogi tersebut harus benarbenar dikenal oleh pebelajar, dan 2) adanya pemetaan kemiripan antara fiturfitur domain analogi (objek atau peristiwa yang dikenal) dan domain target (konsep sains) (Duit dalam Harrison \& Jong, 2005). Setiap analogi memiliki bagian-bagian yang cocok dengan konsep ilmiah, tetapi juga ada bagian lainnya yang tidak cocok. Atas dasar itu, dalam pembelajaran pendidik harus mendiskusikan dan memetakannya bersama pebelajar, serta memberikan penekanan agar pebelajar tidak menjadikan analogi sebagai konsep pembelajaran (Harrison \& Treagust, 2000).

Mengingat tidak ada analogi mampu mencakup seluruh fitur target, maka perlu digunakan analogi ganda untuk mewakili lebih banyak fitur domain target, khususnya ketika konsep target bersifat kompleks dan abstrak (Thagard dalam Harrison \& Jong, 2005). Dengan cara demikian, pebelajar harus mampu bergeser dari satu analogi ke analogi lain untuk menjelaskan konsep-konsep kimia target yang bersifat abstrak. Analogi juga akan berperan sebagai penghubung agar konsep-konsep yang dipelajari menjadi lebih akrab dan mudah dimengerti, serta memberikan landasan bagi pebelajar dalam membangun konsep baru (Treagust, 2008).

Selain membuat pembelajaran menjadi lebih menyenangkan dan bermakna (enjoyfull and meaningfull learning), pembelajaran dengan menggunakan analogi juga berpotensi menimbulkan terjadinya miskonsepsi. Miskonsepsi terjadi karena fitur-fitur analog tidak cocok dengan domain target atau tidak dipetakan dengan baik. Akibatnya, fitur-fitur yang tidak relevan pada analog sering ditafsirkan oleh pebelajar sebagai atribut bersama dengan target. Hal itu tidak hanya terjadi pada analogi-analogi buatan guru (pendidik), tetapi juga pada berbagai analogi yang dibuat oleh para penulis buku-buku teks Kimia (Suja, 2011; Suja \& Retug, 2013a).

Sehubungan

dengan permasalahan tersebut, telah dilakukan penelitian inventarisasi berbagai analogi yang biasa digunakan oleh guru-guru kimia di kota Singaraja, Bali dalam mengajarkan konsep-konsep kimia di SMA. Tujuan penelitian ini adalah untuk menentukan dan mendeskripsikan analogi-analogi yang biasa digunakan oleh guru-guru Kimia SMA dalam mengajarkan konsep-konsep Kimia. Analogi-analogi yang telah terbukti efektif digunakan dalam pembelajaran Kimia dan teruji lewat pengalaman mengajar guru-guru di lapangan, dapat diadopsi dan dikembangkan oleh guruguru pemula untuk mengajarkan konsep-konsep Kimia, khususnya yang bersifat abstrak-teotitis.

\section{METODE}

Penelitian ini dilakukan pada bulan Juli - Oktober 2013 di Kota Singaraja. 
Pengumpulan data dilakukan dengan menggunakan daftar isian dan melibatkan guru-guru Kimia SMA sebagai responden. Total responden sebanyak 10 orang guru senior, masingmasing 2 orang dari setiap SMA Negeri dan Swasta yang ada di Kota Singaraja, yang memiliki Jurusan IPA, yaitu SMA Negeri 1 Singaraja, SMA Negeri 2 Singaraja, SMA Negeri 3 Singaraja, SMA Negeri 4 Singaraja, dan SMA Lab UNDIKSHA Singaraja. Analisis data dilakukan secara deskriptif kualitatif.

\section{HASIL DAN PEMBAHASAN}

Hasil penelitian ini menunjukkan, bahwa dalam mengajarkan konsepkonsep Kimia yang bersifat abstrakteoritis, guru-guru Kimia SMA di kota Singaraja menggunakan tidak kurang dari 12 kelompok analogi sesuai dengan pokok bahasan Kimia yang diajarkan di SMA. Uraian analogi-analogi tersebut dapat dipaparkan sebagai berikut.

\section{Berbagai analogi untuk menje-} laskan model atom. Model atom Dalton menghipotesiskan atom-atom suatu unsur bersifat identik berbentuk bola pejal, seperti mortil dalam permainan tolak peluru (Gambar 1). Dengan ditemukannya elek-tron, model atom Thomson digambarkan sebagai bola padat bermuatan positif, dan di permukaannya tersebar elektron yang bermuatan negatif. Model atom tersebut dianalogikan dengan roti kismis (Gambar 2). Selanjutnya, model atom Bohr meng-hipotesiskan elektronelektron berputar mengelilingi inti atom yang bermuatan positif pada lintasan tertentu. Model atom Bohr dianalogikan dengan Sistem Tata Surya (Gambar 3), matahari sebagai inti atom, dan planet- planetnya sebagai elektron. Pengisian elektron pada kulit-kulit atom dimulai dari tingkat energi yang paling rendah ke tingkat energi yang lebih tinggi, seperti orang naik tangga dimulai dari anak tangga yang paling bawah ke anak tangga berikutnnya di sebelah atasnya.
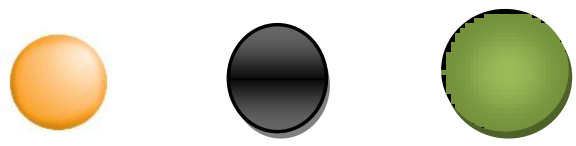

Gambar 1. Model Atom Bola Pejal Dalton

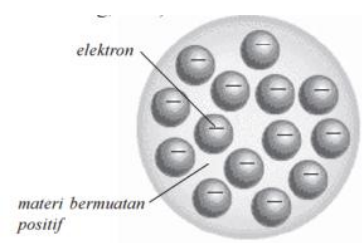

Gambar 2. Model Atom Roti Kismis Thomson

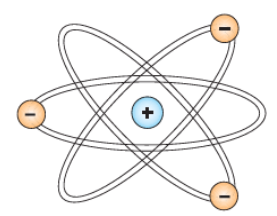

Gambar 3. Model Atom Tata Surya

Analogi penggolongan unsur
logam non logam. Pemikiran dikotomis unsur logam non logam menimbulkan masalah karena ada golongan ketiga yang susah dimasukkan ke dalam salah satu kelompok tersebut. Kelompok ketiga ini menunjukkan kemiripan sifat pada kedua kelompok yang ada, dan secara tersendiri dimasukkan ke dalam kelompok unsur-unsur metaloid. Kondisi ini dianalogikan dengan jenis kelamin: laki-laki dan perempuan, menyisakan kelompok banci. Sifat

Jurnal Pendidikan Indonesia | 399 
orang banci merupakan irisan sifat lakilaki dan perempuan. Jika logam dianalogikan dengan laki-laki, dan perempuan sebagai non logam, maka banci adalah metaloid. Matrik hubungan dikotomi jenis kelamin dan jenis unsur dapat dilihat pada Tabel 1.

Tabel 1. Analogi dikotomi jenis kelaminjenis unsur

\begin{tabular}{ccc}
\hline Laki-laki & Banci & Perempuan \\
\hline \multirow{0}{L}{} & $?$ & $q$ \\
\hline Logam & Metaloid & Non logam \\
\hline
\end{tabular}

Analogi ikatan kimia. Setiap atom cenderung mencapai konfigurasi elekton stabil, seperti Gas Mulia, melalui ikatan dengan atom-atom lain. Ikatan kimia terbentuk melalui pelepasan/ penangkapan (transfer) elektron atau pemakaian pasangan elektron bersama. Ikatan kimia yang terbentuk melalui transfer elektron disebut ikatan ion. Pembentukan ikatan ion dapat dianalogikan dengan orang donor darah. Orang yang mendonorkan darahnya merasa bahagia karena telah dapat membantu orang lain, demikian juga akseptor yang menerima darah tersebut. Dalam kasus tersebut, satu kantong darah yang ditransfer dari donor ke akseptor dianalogikan sebagai elektron yang terlibat dalam pembentukan ikatan ion.

Untuk membentuk ikatan kovalen, atom-atom yang akan berikatan harus mengeluarkan elektron untuk membentuk pasangan elektron ikatan. Analoginya, dua orang siswa yang tidak memiliki buku Kimia secara patungan membeli satu buku. Setelah dibeli, buku tersebut menjadi milik mereka berdua dan menjadi pengikat persahabatan mereka. Jika pasangan elektron yang dipakai bersama hanya berasal dari salah satu atom, maka yang terbentuk adalah ikatan kovalen koordinasi. Hal ini dapat dianalogikan seperti dua orang siswa yang duduk sebangku, satu anak memiliki dua buku teks, sedangkan yang lainnya tidak punya. Anak yang memiliki buku memberikan buku tersebut untuk dimiliki bersama (bukan meminjamkan) dengan temannya yang sebangku. Dengan demikian, kedua siswa tersebut memiliki dua buku teks yang dapat dipakainya bersama-sama.

Analogi bentuk molekul dan polaritas ikatan. Pasangan elektron ikatan dan pasangan elektron bebas yang ada di sekitar atom pusat saling tolak-menolak satu dengan lainnya. Akibatnya, atom-atom yang berikatan akan membentuk struktur tertentu dan dikenal sebagai bentuk molekul. Untuk memvisualisasikan bentuk molekul guruguru menggunakan analogi balon sebagai model orbital molekul. Balon diisi udara kemudian diikat bersama balon-balon lain sebagai bentuk riil orbital molekul, sebagaimana ditampilkan dalam Gambar 4.
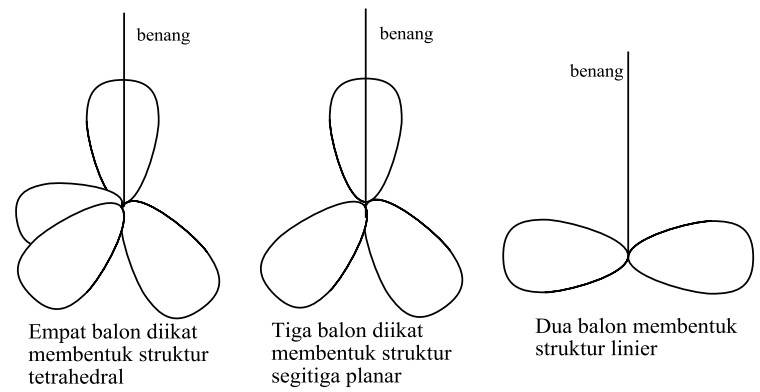

Gambar 4. Analogi balon untuk bentuk molekul

Jurnal Pendidikan Indonesia | 400 
Kekuatan atom-atom yang berikatan untuk menarik pasangan elektron ikatannya tergantung pada jenis atomnya. Kondisi ini dianalogikan dengan dua orang yang bersalaman dan saling tarik. Orang yang lebih kuat menarik menyebabkan kepalan tangan yang bersalaman lebih mendekatinya. Sebaliknya, yang lebih lemah akan dijauhi oleh kepalan tangan tersebut. Dalam kasus ini, kepalan tangan yang bersalaman melambangkan pasangan elektron ikatan. Atom yang lebih kuat menarik pasangan elektron ikatan bersifat lebih elektronegatif dan bermuatan parsial negatif. Sebaliknya, atom yang kurang kuat menarik pasangan elektron ikatan akan mengemban muatan parsial positif. Dalam kasus tersebut, ikatan yang terjadi antara kedua atom akan bersifat polar.

Analogi pereaksi pembatas. Pereaksi pembatas adalah reaktan yang habis bereaksi dalam suatu reaksi kimia. Guru-guru menganalogikan dengan seorang ibu yang hendak membuat es krim. Untuk membuat 1 gelas es krim coklat diperlukan 2 sendok es krim, 1 buah chery, dan $50 \mathrm{~mL}$ susu coklat. Berapa gelas es krim coklat bisa dibuat dari 8 sendok es krim, 6 buah chery, dan $100 \mathrm{~mL}$ susu coklat? Dengan perbandingan sederhana, pebelajar akan dapat menentukan jumlah es krim yang dapat dibuat, jumlah masingmasing bahan yang diperlukan, bahan yang habis digunakan (analog dengan pereaksi pembatas) dan bahan-bahan yang tersisa. Dalam kasus tersebut, susu coklat seolah-olah bertindak sebagai "pereaksi pembatas" karena merupakan bahan yang habis terpakai.
Ilustrasi proses tersebut dapat dilihat pada Gambar 5.

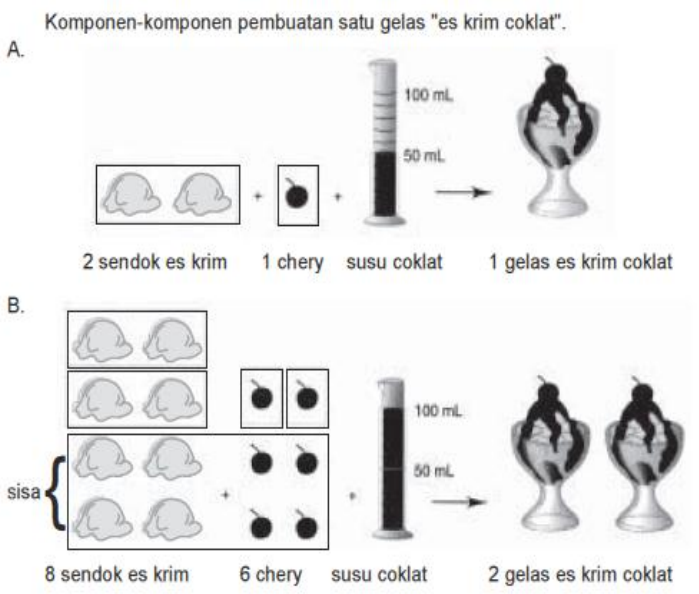

Sumber: Silberberg, Chemistry: The Molecular Nature of Matter and Change

Gambar 5. Pembuatan es krim

Analogi perubahan entalpi. Jumlah energi yang dikandung oleh suatu zat tidak dapat diukur langsung, yang bisa diukur hanya perubahan energinya. Hal ini dianalogikan oleh guru-guru dengan jumlah air yang ada dalam suatu jubang di Bukit Kintamani. Volume air dalam jubang tersebut tidak dapat diketahui secara pasti, tetapi kita dapat menentukan perubahan volumenya setelah melihat seseorang mengambil satu ember air dari dalam jubang tersebut. Analogi lain adalah jumlah uang yang dibawa oleh seseorang yang berbelanja di swalayan. Pengurangan jumlah uang pembeli tersebut dapat diketahui dari besarnya transaksi yang dia lakukan di kasir dan itu sama dengan perubahan entalpi. Sedangkan, jumlah uang yang dimilikinya tidak bisa kita tentukan.

Menurut Hukum Hess, perubahan entalpi tidak dipengaruhi oleh jalannya reaksi (proses), tetapi hanya ditentukan

Jurnal Pendidikan Indonesia | 401 
oleh keadaan awal dan akhir reaksi (fungsi keadaan). Kondisi itu dianalogikan oleh guru-guru dengan jarak antara dua kota, A dan B, tidak tergantung pada rute yang dilalui oleh beberapa pengendara sepeda motor yang berangkat dari kota $A$ menuju kota $B$ melalui jalan berbeda. Analogi lain yang digunakan oleh guru-guru adalah dua orang yang naik dari lantai dasar ke lantai tiga dari sebuah gedung dengan menggunakan lift dan eskalator. Satu orang langsung menuju ke lantai tiga menggunakan lift. Orang yang lainnya, naik eskalator dari lantai dasar ke lantai satu. Setelah berjalan beberapa lama di lantai satu dia kembali naik eskalator menuju ke lantai dua. Hal yang sama dilakukannya hingga sampai di lantai tiga, dan bertemu dengan orang pertama. Walaupun ke dua orang tersebut menempuh rute berbeda, namun mereka berdiri pada ketinggian yang sama jika diukur dari lantai dasar.

Analogi laju reaksi. Menurut teori tumbukan, reaksi terjadi jika ada tumbukan efektif antar partikel-partikel zat yang bereaksi. Syarat tumbukan efektif ada dua, yaitu: orientasinya tepat, dan energinya cukup besar. Energi minimal yang harus dimiliki oleh partikelpartikel zat agar dapat bereaksi disebut energi aktivasi $\left(E_{a}\right)$, yang dianalogikan dengan jalan tanjakan pada sebuah perbukitan. Laju reaksi dipengaruhi oleh konsentrasi zat-zat yang bereaksi; semakin tinggi konsentrasi, semakin cepat laju reaksinya. Hal ini dianalogikan dengan peluang terjadinya tabrakan antar kendaraan bermotor di jalan sempit yang ramai dibandingkan di jalan lebar dan sepi. Keadaan kendaraan yang berdesak-desakan dengan kecepatan tinggi memberikan peluang besar terjadinya tabrakan. Analogi lain yang digunakan guru adalah pembuatan larutan nutrisari. Semakin banyak serbuk nutrisari dilarutkan ke dalam segelas air dan diaduk, semakin banyak gelembunggelembung gas yang terbentuk, dan menandakan reaksi itu berlangsung semakin cepat.

Laju reaksi dapat dipercepat dengan penambahan katalis karena dapat menurunkan energi aktivasi. Hal itu dapat dianalogikan dengan pembuatan jalan sodetan berupa terowongan, sehingga kendaraan tidak perlu lagi melalui jalan tanjakan (Gambar 6). Selain itu, guru-guru juga menggunakan analogi Mak Comblang untuk menjelaskan peran katalis dalam laju reaksi.

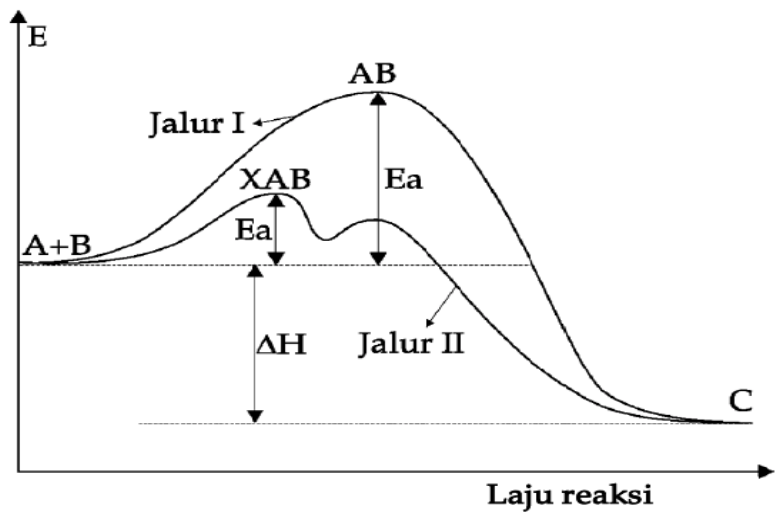

Gambar 6. Koordinat energi potensial. Jalur I tanpa katalis, jalur II dengan katalis

Dalam sistem biologis, laju reaksi dipercepat oleh enzim sebagai biokatalisator. Enzim tersebut bekerja sangat spesifik, artinya hanya dapat mempercepat reaksi tertentu saja. Sebagai contoh, enzim amilase dapat menghidrolisis (memecah) molekulmolekul pati (polisakarida) menjadi

Jurnal Pendidikan Indonesia | 402 
molekul-molekul maltosa (disakarida). Mekanisme kerja enzim tersebut dapat dianalogikan dengan gembok dan kunci (lock and key), seperti ditampilkan pada Gambar 7.
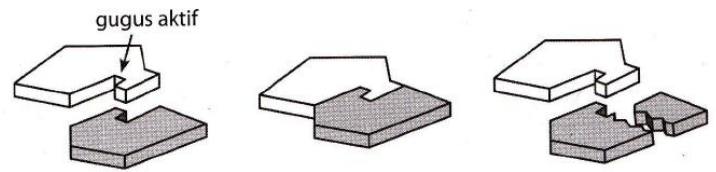

enzim + substrat enzim - substrat enzim + produk-produ
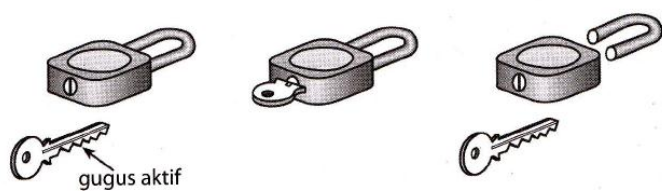

Gambar 7. Diagram analogi gembok dan kunci untuk kerja enzim (Sumber gambar Harrison \& Coll, 2008)

Laju reaksi juga ditentukan oleh luas permukaan zat-zat yang bereaksi. Untuk jumlah zat sama, semakin kecil ukuran zat-zat bereaksi atau semakin luas ukuran bidang sentuh reaksinya, laju reaksinya akan berlangsung semakin cepat. Kondisi ini dianalogikan dengan pembakaran kayu. Kayu bakar yang dibelah-belah atau dipotongpotong menjadi bagian-bagaian yang lebih kecil akan lebih cepat terbakar dibandingkan kayu gelondongan (Gambar 8).
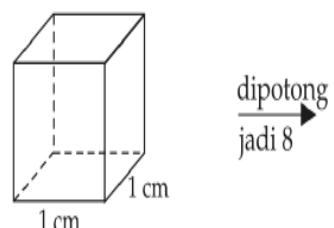

Terdapat 1 luas permukaan kubus

Terdapat 8 luas permukaan kubus
Gambar 8. Ilustrasi luas permukaan zat
Analogi kesetimbangan kimia. Kesetimbangan kimia tercapai pada saat laju pembentukan produk sama dengan penguraian produk kembali menjadi reaktan. Ditemukan ada lima analogi digunakan oleh guru-guru kimia untuk mengajarkan konsep kesetimbangan kimia. Pertama, permainan jungkat-jungkit yang ada di TK. Kedua, pengunjung toko. Pada suatu saat di toko buku yang berlantai dua, jumlah pengunjung yang naik dan turun melalui eskalator sama jumlahnya. Tidak ada lagi pengunjung yang datang atau keluar meninggalkan toko. Jumlah pengunjung di masing-masing lantai tidak berubah, walaupun tidak sama jumlahnya. Pengunjung toko buku tersebut telah mengalami kesetimbangan. Ketiga, sebuah perhiasaan tembok rumah dibuat dalam bentuk kolam di bagian bawah dan waduk kecil di bagian atasnya. Dari waduk air dialirkan melalui alur menyerupai sungai dan pancuran jatuh ke kolam, sebaliknya dari kolam ditarik kembali ke waduk di atasnya menggunakan selang dengan bantuan dinamo (energi listrik). Suatu saat jumlah air yang keluar masuk waduk dan kolam sama banyaknya. Pada saat itu sistem kolam-waduk telah mencapai kesetimbangan, walaupun volume air di kolam tidak sama dengan di dalam waduk.

Analogi keempat yang digunakan untuk menjelaskan keadaan kesetimbangan oleh guru-guru kimia adalah permainan sirkus. Misalkan, ada seekor burung mencoba berjalan pada roda berputar. Burung berjalan ke kiri, sedangkan roda berputar ke kanan. Jika kecepatan roda berputar ke kanan sama dengan kecepatan burung

Jurnal Pendidikan Indonesia | 403 
tersebut berjalan ke kiri, maka posisi burung tersebut akan tetap dan kelihatan diam. Keadaan tersebut dinamakan kesetimbangan dinamis, sebab burung tersebut kelihatannya saja diam, tetapi sesungguhnya kaki-kakinya terus bergerak berlawanan arah dengan perputaran roda, namun dengan kecepatan sama. Analogi kelima yang digunakan oleh guru-guru kimia untuk menggambarkan kesetimbangan adalah permainan sirkus lempar botol. Pemain sirkus memainkan tiga buah botol dengan melemparkan dan menangkapnya. Setiap saat, satu botol terpegang di tangan kiri, dan satu botol di tangan kanannya, serta satu botol lainnya dilemparkan di udara.

Pergeseran kesetimbangan dianalo-gikan dengan posisi permukaan air pada sebuah tabung U (Gambar 9). Jika ke dalam salah satu mulut tabung $U$ tersebut ditambahkan air, maka air dalam bagian tabung tersebut akan bergeser ke bagian lainnya, sehingga permukaan air di bagian yang lainnya akan meningkat dan terbentuk keadaan kesetimbangan yang baru. Sebaliknya, jika air diambil dari salah satu mulut tabung, maka air akan mengalir dari bagian yang lainnya, sampai terbentuk kesetimbangan yang baru.

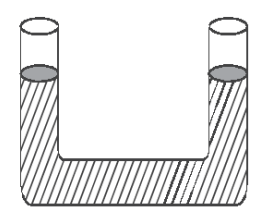

Gambar 9. Air dalam tabung U

Analogi reaksi netralisasi. Reaksi netralisasi adalah reaksi antara asam dari basa menghasilkan garam dan air. Seorang guru kimia membuat analogi "kancing baju" dan lubangnya untuk menjelaskan reaksi netraliasi. Kancing baju melambangnya proton $\left(\mathrm{H}^{+}\right)$dan lubangnya melambangkan ion hidroksida $\left(\mathrm{OH}^{-}\right)$. Pemasukan kancing baju ke dalam lubangnya melambangkan reaksi kimia. Menyatunya kedua bagian kain baju dipandang sebagai pembentukan garam, dan kancing baju yang telah terpasang serta tampak keluar melambangkan molekul air $\left(\mathrm{H}_{2} \mathrm{O}\right)$.

Sifat larutan yang terbentuk dari reaksi netralisasi tidak selalu netral, tetapi tergantung pada kekuatan asam basa yang bereaksi. Kondisi ini dapat dianalogikan dengan pembentukan keluarga kecil yang terdiri dari seorang suami dan seorang isteri. Suasana rumah tangga ditentukan oleh sifat suami dan isterinya. Karakter yang lebih kuat dari mereka berdua akan menentukan karakter keluarganya. Demikian juga dengan sifat asam-basa yang bereaksi. Jika asam dan basa yang bereaksi sama kuatnya, maka larutan garam yang terbentuk bersifat netral. Jika sifat asam penyusunnya lebih kuat, maka larutan garamnya akan bersifat asam. Sebaliknya, jika sifat basa penyusunnya lebih kuat, maka larutan garamnya akan bersifat basa.

Analogi gugus fungsional. Gugus fungsi adalah atom atau kelompok atom yang menentukan sifat senyawa organik. Gugus fungsional ibarat kepala pada diri manusia atau sopir/pengendara pada mobil/ sepeda (Gambar 10) Kepala yang menentukan sifat dan karakter manusia, sopir yang menentukan gerakan mobil yang dikendarainya; demikian juga dengan 
gugus fungsi dalam senyawa organik. Kereaktivan dan jenis reaksi yang akan dialami oleh sebuah molekul organik ditentukan oleh gugus fungsinya.

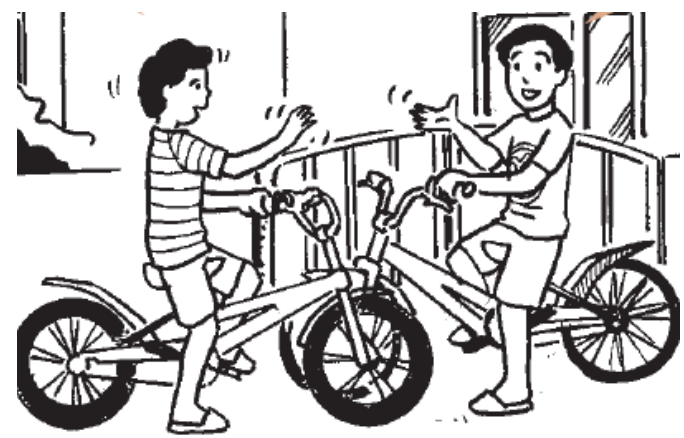

Gambar 10. Pengendara sepeda analog gugus fungsi senyawa organik (Sumber gambar: Pusbuk Depdiknas)

Analogi struktur resonansi benzena. Struktur senyawa benzena $\left(\mathrm{C}_{6} \mathrm{H}_{6}\right)$ tidak dapat digambarkan secara pasti. Struktur siklis senyawa tersebut mendapat inspirasi dari mimpi Kekule tentang seekor ular yang menggigit ekornya. Struktur nyatanya merupakan komposit dari dua struktur resonansi berikut.<smiles>c1ccc(Nc2ccccc2)cc1</smiles>

Struktur resonan benzena (bukan struktur yang sebenarnya)

Struktur resonansi dapat dianalogikan dengan sosok artis Sukma Ayu pada masa lampau. Sukma Ayu: artis (makhluk nyata), tetapi tidak diketahui oleh penerima informasi pada masa kini. Kepalanya botak seperti tuyul (makhluk tidak nyata), tetapi cantik seperti bidadari (makhluk tidak nyata). Sukma Ayu tidak bergeser bolak balik dari tuyul ke bidadari, melainkan merupakan makhluk nyata dengan karakteristik tuyul dan bidadari kedua-duanya. Analogi lain yang juga digunakan oleh guru-guru untuk menjelaskan resonasi adalah badak (binatang nyata), yang dapat digambarkan sebagai hibrida resonansi antara kuda bertanduk "unicorn" (binatang khayalan) dan naga (binatang khayalan). Seekor badak tidak bergeser bolak-balik dari unicorn ke naga, tetapi sebagai binatang nyata dengan karakteristik antara unicorn dan naga secara bersamaan.

Analogi reaksi polimerisasi. Polimerisasi adalah penggabungan molekul-molekul sederhana membentuk rantai panjang. Hasil reaksi polimerisasi disebut polimer, sedangkan molekul sederhana pembentuk polimer dinamakan monomer. Penggabungan monomer-monomer tidak jenuh (berikatan rangkap) membentuk polimer jenuh (ikatan tunggal) disebut polimerisasi adisi. Reaksinya melibatkan pemutusan ikatan pi dan pembentukan ikatan sigma. Reaksi ini dianalogikan oleh guru-guru kimia dengan permainan berikut. Setiap dua orang anak membentuk lingkaran kecil dengan saling berpegangan tangan satu dengan lainnya (sebagai monomer). Selanjutnya, seluruh anak disuruh membentuk lingkaran besar dengan jalan melepaskan satu pegangannya untuk digunakan berpegangan tangan dengan kelompok lain (membentuk polimer).

Jika polimeisasi terjadi antara monomer-monomer yang minimal memiliki dua gugus fungsi dan disertai dengan pelepasan molekul sederhana, maka polimer yang terbentuk disebut polimer kondensasi. Analoginya, setiap

Jurnal Pendidikan Indonesia | 405 
anak sebagai monomer memegang huruf $\mathrm{H}$ di tangan kiri dan huruf $\mathrm{X}$ di tangan kanan. Mereka disuruh berdiri bershap (berjejer ke samping). Selanjutnya, diperintahkan untuk saling berpegangan tangan dengan melepaskan huruf-huruf yang dipegangnya. Setiap jabat tangan akan disertai pelepasan "rumus molekul" $H X$, dan anak-anak tersebut akan membentuk rantai panjang polimer.

Berbagai analogi yang digunakan oleh guru-guru Kimia SMA dalam mengajarkan konsep-konsep Kimia telah teruji lewat pengalaman di kelas Kimia. Analogi-analogi tersebut ada merupakan hasil kreasi guru, tetapi ada pula diperolehnya dari buku-buku teks Kimia. Penggunaan analogi-analogi tersebut tergolong tunggal, serta tidak ada pemetaan persamaan fitur antara analog dan konsep target. Kondisi itu berpeluang menimbulkan terjadinya kesalahan penafsiran dan miskonsepsi bagi pebelajar (Widhiyanti, 2006), yang disebabkan oleh beberapa faktor berikut.

Pertama, analogi permainan jungkat-jungkit dan tabung $U$ untuk mengilus-trasikan kesetimbangan kimia menunjukkan fitur penting yang tidak relevan. Permainan jungkat-jungkit dan air dalam tabung $U$ merupakan contoh keseimbangan (balance) yang bersifat statis. Sedangkan, kesetimbangan kimia (equilibrium) bersifat dinamis. Kesetimbangan kimia tidak bisa dimodelkan dengan sesuatu yang statis karena secara mikroskopis reaksi tetap berlangsung ke kedua arah dengan kecepatan sama (Suja, 2011). Atas dasar itu, kondisi kesetimbangan mesti dimodelkan dengan sesuatu yang juga bersifat dinamis, misalnya model "school dance" oleh Harrison \& Treagust (2000). Pada keadaan kesetimbangan, secara makroskopis tidak ada perubahan yang dapat diamati, namun secara submikroskopis reaksi tetap berlangsung ke kedua arah dengan laju sama.

Kedua, penafsiran analogi bisa keluar fitur-fitur bersama analog-target. Sebagai contoh, penggunaan analogi orang naik ke lantai atas pada suatu gedung bertingkat dengan menggunakan lift serta eskalator dan berjalan kaki, bisa ditanggapi berbeda oleh pebelajar. Analogi tersebut hendak menggambarkan, walaupun mereka menempuh jalan berbeda, namun perubahan energi potensial yang ditunjukkan oleh ketinggiannya dari lantai dasar adalah sama. Tanpa penjelasan yang memadai, pebelajar bisa memandang bahwa orang yang naik lift akan memerlukan energi lebih rendah dibandingkan dengan yang naik eskalator dan berjalan kaki.

Menurut Harrison \& Coll (2008), untuk mengarahkan penafsiran terhadap analogi, dapat digunakan metode FAR (fokus-aksi-refleksi).

Fokus: memastikan para pebelajar mengetahui argumentasi pendidik menggunakan analogi. Aksi: memastikan para pebelajar mengenal objek atau pengalaman keseharian yang ingin digunakan sebagai analog. Selain itu, memastikan bahwa pendidik selalu mendiskusikan bagian dari analog yang dapat digunakan (sifat mirip) dan tidak dapat digunakan (sifat berbeda). Refleksi: mengevaluasi keefektivan penggunaan analogi, serta menanyakan pada diri sendiri tentang perlunya merevisi penjelasan dan mencari cara lain yang lebih baik dalam 
menggunakan analogi tersebut di lain waktu. Contoh langkah-langkah implementasi metode FAR dalam mengajarkan konsep kesetimbangan kimia dengan analogi pesta dansa di sekolah dapat dilihat pada Tabel 2.

Tabel 2. Langkah-langkah Metode FAR Analogi Pesta Dansa di Sekolah untuk Kesetimbangan Kimia (Harrison \& Coll, 2008)

\begin{tabular}{|c|c|c|c|}
\hline Tahap & Unsur & \multicolumn{2}{|c|}{ Penjelasan } \\
\hline \multirow[t]{3}{*}{ Fokus } & Konsep & \multicolumn{2}{|c|}{$\begin{array}{l}\text { Dalam reaksi yang dapat balik, pada awal reaksi hanya ada } \\
\text { reaktan. Selama reaksi berlangsung, produk terbentuk dan } \\
\text { jumlah reaktan berkurang. Pada saat yang sama, beberapa } \\
\text { produk kembali terurai menjadi reaktan melalui reaksi balik. } \\
\text { Pada saat kecepatan pembentukan produk sama dengan } \\
\text { penguraiannya, reaksi dinyatakan ada dalam keadaan } \\
\text { setimbang. Pada saat tersebut tidak terjadi perubahan } \\
\text { konsentrasi reaktan maupun produk, walaupun reaksi tetap } \\
\text { berlangsung ke kedua arah. }\end{array}$} \\
\hline & Pebelajar & \multicolumn{2}{|c|}{$\begin{array}{l}\text { Pebelajar memiliki kesulitan dalam membayangkan sifat } \\
\text { dinamis kesetimbangan. Mereka bisa mengira reaksi telah } \\
\text { berhenti pada saat terjadi kesetimbangan. }\end{array}$} \\
\hline & Analog & \multicolumn{2}{|c|}{$\begin{array}{l}\text { Ada } 500 \text { anak laki-laki dan } 500 \text { anak perempuan. Setiap } \\
\text { murid harus berjalan berkeliling aula sampai menemukan } \\
\text { pasangannya, setelah itu mereka bisa pergi ke ruang dansa } \\
\text { yang hanya memiliki kapasitas } 250 \text { pasang penari. Pintu } \\
\text { ruang dansa dijaga oleh guru. Setelah kapasitas } 250 \text { pasang } \\
\text { terpenuhi, pasangan baru bisa masuk ruang dansa jika ada } \\
\text { pasangan lain terlebih dulu meninggalkan ruangan. }\end{array}$} \\
\hline \multirow[t]{7}{*}{ Aksi } & \multicolumn{3}{|c|}{ Kemiripan - Pemetaan analog dengan target } \\
\hline & & $\begin{array}{l}\text { Analog-Pesta dansa di } \\
\text { sekolah }\end{array}$ & Target-Kesetimbangan \\
\hline & & $\begin{array}{l}\text { Para murid berdansa di aula } \\
\text { (pereaksi) }\end{array}$ & $\begin{array}{l}\text { Partikel-partikel bergerak dan } \\
\text { bertumbukan }\end{array}$ \\
\hline & & $\begin{array}{l}\text { Komitmen di antara para } \\
\text { murid }\end{array}$ & $\begin{array}{l}\text { Pembentukan ikatan kimia } \\
\text { (dan produk) }\end{array}$ \\
\hline & & $\begin{array}{l}\text { Sejumlah murid di dalam } \\
\text { aula }\end{array}$ & $\begin{array}{l}\text { Pengaruh konsentrasi pada } \\
\text { laju reaksi }\end{array}$ \\
\hline & & $\begin{array}{l}\text { Perubahan ukuran aula } \\
\text { (untuk jumlah murid yang } \\
\text { sama) }\end{array}$ & $\begin{array}{l}\text { Pengaruh konsentrasi pada } \\
\text { laju reaksi }\end{array}$ \\
\hline & & $\begin{array}{l}\text { Kelincahan murid-murid } \\
\text { berdansa }\end{array}$ & $\begin{array}{l}\text { Pengaruh suhu pada laju } \\
\text { reaksi }\end{array}$ \\
\hline
\end{tabular}




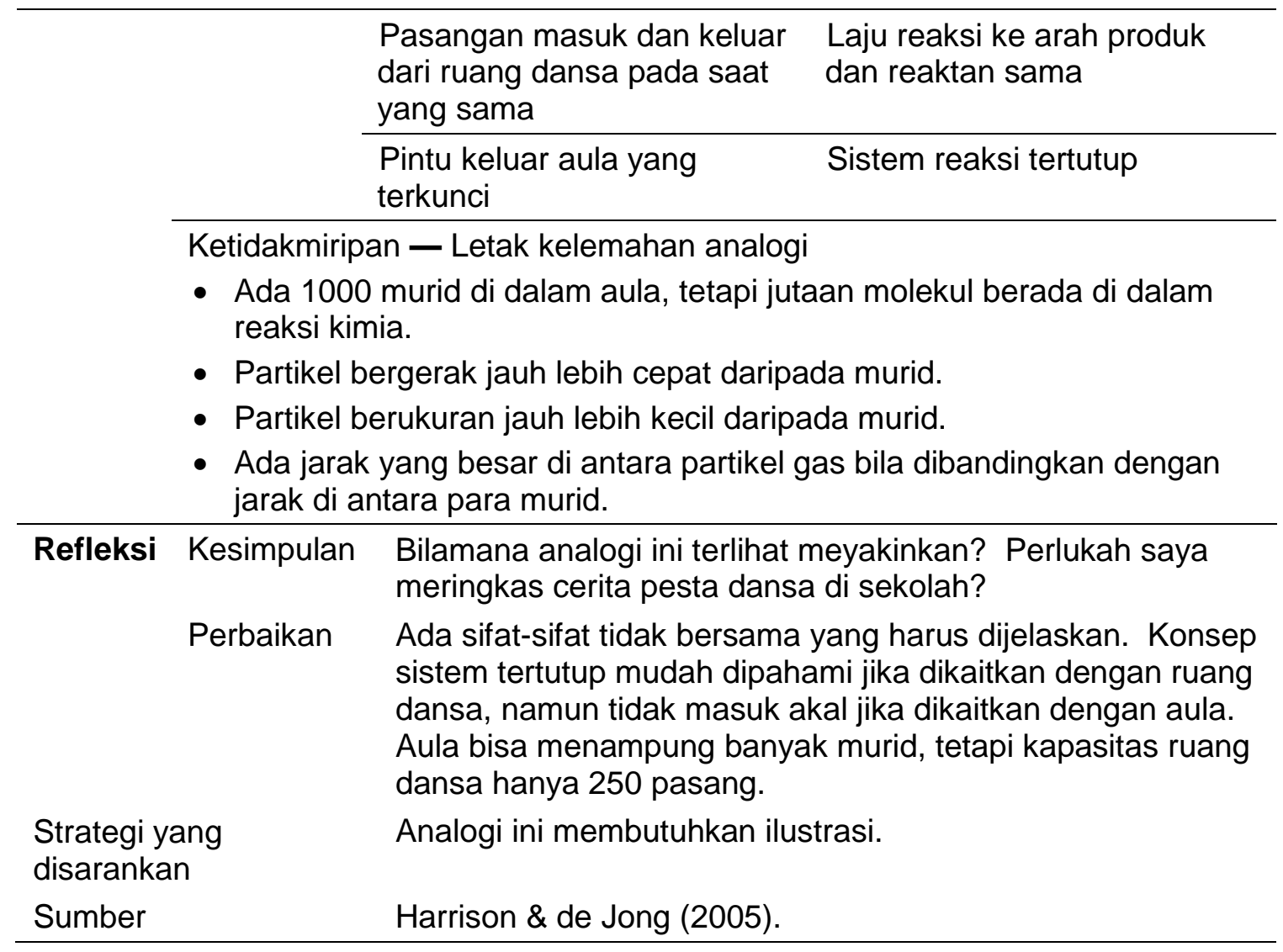

Menurut Harrison \& Coll (2008), pembelajaran dengan menggunakan analogi merupakan cara yang cerdas dan efektif dalam menjelaskan topiktopik sains, khususnya yang bersifat abstrak-teoritis, sehingga menjadi menyenangkan dan menimbulkan motivasi bagi pebelajar. Agar memiliki pemahaman yang utuh tentang konsep kimia, guru perlu mengajarkan konsep tersebut dengan beberapa analogi. Dengan cara demikian, lebih banyak fitur dalam konsep target bisa dipahami dengan bantuan fitur-fitur bersama dalam analog-analog yang digunakan (Harrison \& Jong, 2005). Sebagai contoh, dalam Tabel 3 berikut ditampilkan analogi ganda untuk menjelaskan laju reaksi. 
Tabel 3. Multi Analogi untuk menjelaskan Laju Reaksi

\begin{tabular}{cll}
\hline No & $\begin{array}{l}\text { Analogi, sesuai urutan pada } \\
\text { pertemuan pokok bahasan laju } \\
\text { reaksi }\end{array}$ & Konsep laju reaksi \\
\hline 1 & Jalan raya yang sibuk & $\begin{array}{l}\text { Reaksi terjadi karena adanya tumbukan } \\
\text { yang efektif }\end{array}$ \\
\hline 2 & Jalan tanjakan melalui perbukitan & $\begin{array}{l}\text { Energi aktivasi: energi minimal yang } \\
\text { harus dimiliki oleh partikel-partikel zat } \\
\text { agar dapat bereaksi. }\end{array}$ \\
\hline 3 & $\begin{array}{l}\text { Penambahan jumlah kendaraan } \\
\text { dengan fasilitas jalan tetap. }\end{array}$ & $\begin{array}{l}\text { Pengaruh perubahan konsentrasi } \\
\text { terhadap laju reaksi }\end{array}$ \\
\hline 4 & $\begin{array}{l}\text { Naik kendaraan dengan kecepatan } \\
\text { tinggi }\end{array}$ & $\begin{array}{l}\text { Pengaruh peningkatan suhu terhadap laju } \\
\text { reaksi }\end{array}$ \\
\hline 5 & $\begin{array}{l}\text { Pembuatan terowongan untuk } \\
\text { mengatasi jalan tanjakan }\end{array}$ & $\begin{array}{l}\text { Pengaruh penambahan katalis terhadap } \\
\text { laju reaksi }\end{array}$ \\
\hline 6. & Lomba lari estafet di jalan raya & Mekanisme reaksi \\
\hline 7 & Lomba lari estafet & $\begin{array}{l}\text { Tahap penentu laju reaksi: laju reaksi } \\
\text { ditentukan oleh tahap yang paling lambat }\end{array}$ \\
\hline
\end{tabular}

Penggunaan analogi dalam pembelajaran Kimia memiliki dampak positif sekaligus berpotensi menimbulkan terjadinya miskonsepsi. Menurut Treagust (2008), analogi merupakan bentuk metafora yang bisa mengakrabkan pebelajar dengan konsep-konsep ilmiah yang susah dipahaminya, dan memberikan landasan untuk membangun konsep baru. Pemikiran tersebut sejalan dengan pendekatan konstruktivisme dalam pembelajaran tentang pentingnya pengetahuan awal (prior knowledge) sebagai landasan untuk membangun konsep baru.

Penggunaan analogi dalam pembelajaran kimia, menurut teori memori kode ganda (dual code theory of memory) dari Paivio (Slavin, 2008), menyebabkan struktur partikel-partikel materi dapat disimpan dalam bentuk visual dan verbal, sehingga lebih mudah diingat dan dipanggil kembali pada saat diperlukan, dibandingkan hanya nama partikel materi yang bersifat abstrak.

\section{SIMPULAN DAN SARAN}

Sejalan dengan hasil penelitian dan pembahasan di depan dapat ditarik simpulan, bahwa guru-guru Kimia SMA di Kota Singaraja biasa menggunakan analogi dalam mengajarkan konsepkonsep kimia, khususnya yang bersifat abstrak-teoritis. Ditemukan tidak kurang dari 12 kelompok analogi biasa mereka gunakan dalam pembelajaran Kimia. Penggunaan analogi-analogi tersebut masih bersifat tunggal dan belum disertai pemetaan kemiripan fitur-fitur analog dengan konsep target. Kondisi itu berpeluang menimbulkan terjadinya over interpretasi dan miskonsepsi bagi siswa.

Jurnal Pendidikan Indonesia | 409 
Untuk menghindari terjadinya miskonsepsi dan lebih mengefektifkan penggunaan analogi dalam pembelajaran Kimia, guru-guru disarankan membuat pemetaan kemiripan dan ketidakmiripan fitur-fitur analog dengan konsep target. Data tersebut mesti diinformasikan atau bahkan ikut digali bersama pebelajar di kelas. Selanjutnya, untuk memperjelas pemahaman pebelajar tentang konsepkonsep kimia yang bersifat kompleks, pendidik disarankan menggunakan analogi ganda, sehingga lebih banyak fitur target bisa diperkenalkan kepada pebelajar.

\section{DAFTAR PUSTAKA}

Harrison, A. G., \& Jong, O. D., 2005. "Using multiple analogies: case study of a chemistry teachers' preparations, presentations and reflections." In Boersma, K., et al. (eds). Research and the quality of science education, 353-364. Dordrecht: Springer.

Harrison, A. G., \& Treagust, D. F., 2000. Learning about atom, molecules and chemical bonds: a casestudy. Science Education. 22 (3): 913 1223.

Harrison, A.G. \& Coll, R.K. (Eds.), 2008. Analogi dalam Kelas Sains. Terjemahan Akhlis Nursetiadi, 2013. Jakarta: PT Indeks.

Slavin, R. E., 2008. Educational Psychology Theory and Practice. $8^{\text {th }}$ edition. Boston: Pearson.
Suja, I W., \& Retug, N., 2013a. Profil Konsepsi Kimia Siswa Kelas XI di Kota Singaraja. Prosiding Seminar Nasional Riset Inovatif I Tahun 2013 Lembaga Penelitian Universitas Pendidikan Ganesha. ISSN : 2339-1553, p. $172-179$.

Suja, I W., \& Retug, N., 2013b. Konsepsi Kimia Siswa Kelas XII di Kota Singaraja. Prosiding Seminar Nasional Peningkatan Mutu MIPA dan Pendidikan MIPA untuk Mendukung Implementasi Kurikulum 2013. Diselenggarakan oleh Fakultas MIPA UNDIKSHA, Singaraja, 30 Nopember 2013, p. $125-133$.

Suja, I W., 2011. Membangun Pedagogical Content Knowledge Berbasis Anumana dan Upamana Pramana dalam Pembelajaran Kimia. Jurnal Pendidikan Kimia Indonesia, 1(2): 56 - 63.

Treagust, D. F., 2008. Development and Use of Diagnostic Test to Evaluate Students Misconceptionin Science. International Journal of Science Education, 10 (2): 159-169.

Widhiyanti, T., $2006 . \quad$ Peran Laboratorium dan Multimedia dalam Pembelajaran Kimia pada Salah Satu SMAN di Kabupaten Bogor." Laporan Studi Lapangan SPs UPI Bandung: Tidak diterbitkan. 